\title{
Heliantheae s.l. (Asteraceae) do Parque Estadual do Biribiri, Diamantina, Estado de Minas Gerais, Brasil ${ }^{1}$
}

\author{
Danilo Marques ${ }^{2}$ e Jimi Naoki Nakajima ${ }^{2,3}$
}

Recebido: 12.03.2014; aceito: 7.08.2014

\begin{abstract}
Heliantheae s.l. (Asteraceae) from Parque Estadual do Biribiri, Diamantina, Minas Gerais State, Brazil). Heliantheae s.l., the third largest tribe in the Asteraceae family, has 48 genera and 379 species in Brazil, with 199 species restricted to this country. The tribe is very representative of Espinhaço Range flora, which presents a great diversity and endemism. This work presents the taxonomic treatment of Heliantheae s.l. of Parque Estadual do Biribiri (PEB), located in the Espinhaço Range, Diamantina municipality, Minas Gerais State. It provides an identification key, morphological description, geographic distribution, and taxonomic commentaries for each species. The tribe Heliantheae s.l. in PEB has nine genera and 16 species: Acanthospermum, Aldama, Cosmos, Dimerostemma, Galinsoga, and Melampodium (one species each); Aspilia and Bidens (three spp. each), and Calea (four spp.). The PEB has a great number of species Heliantheae s.l. compared with other areas of Minas Gerais State, and it has $12.5 \%$ of its species restricted to Minas Gerais State, revealing the importance of this park to protect the flora of Espinhaço Range.
\end{abstract}

Keywords: Compositae, endemism, Espinhaço Range, floristics

RESUMO - (Heliantheae s.l. (Asteraceae) do Parque Estadual do Biribiri, Diamantina, Estado de Minas Gerais, Brasil). Heliantheae s.l., a terceira maior tribo da família Asteraceae, possui 48 gêneros e 379 espécies no Brasil, das quais 199 espécies são restritas ao país. A tribo está bem representada na Cadeia do Espinhaço que apresenta grande diversidade e endemismo. Neste trabalho foi realizado o tratamento florístico de Heliantheae s.l. para o Parque Estadual do Biribiri (PEB), localizado na Cadeia do Espinhaço, município de Diamantina, Estado de Minas Gerais. No tratamento é apresentada uma chave de identificação para as espécies, seguida de descrições morfológicas, comentários taxonômicos e distribuição geográfica. A tribo Heliantheae s.l. no PEB possui nove gêneros e 16 espécies: Acanthospermum, Aldama, Cosmos, Dimerostemma, Galinsoga e Melampodium (uma espécie cada), Aspilia e Bidens (três spp. cada) e Calea (quatro spp.). O PEB apresenta grande representatividade de Heliantheae s.l. quando comparado com outras áreas já estudadas no Estado de Minas Gerais. Além disso, 12,5\% das suas espécies são restritas ao Estado, demonstrando a importância do Parque na conservação da flora da Cadeia do Espinhaço no Estado de Minas Gerais.

Palavras chave: Cadeia do Espinhaço, Compositae, endemismo, florística

\section{Introdução}

A Cadeia do Espinhaço é reconhecida pela UNESCO (2005) como uma Reserva da Biosfera. Esse complexo montanhoso, o segundo maior do Brasil, localiza-se entre os Estados da Bahia e de Minas Gerais, com uma extensão de $1.200 \mathrm{~km}$ norte-sul (Giulietti \& Pirani 1988). A principal vegetação dessa região é o campo rupestre, mas ocorrem também manchas de cerrado e de mata de galeria (Giulietti et al. 1987). Sem dúvida, a Cadeia do Espinhaço é uma das regiões mais diversificadas do mundo, com mais de 3.000 espécies vegetais, das quais muitas são endêmicas (Giulietti et al. 2000).

Neste sentido, na década de 1990 foram criados diversos Parques Estaduais na Cadeia do Espinhaço com o objetivo de preservar esta rica flora, tais como o Parque Estadual da Serra do Rola-Moça, Parque Estadual do Rio Preto, Parque Estadual do Pico do Itambé e o Parque Estadual do Biribiri (Vitta 2002).

O Parque Estadual do Biribiri (PEB) está localizado em uma região da porção mineira da Cadeia do Espinhaço, conhecida como Platô ou Planalto de

1. Parte da Dissertação de Mestrado do primeiro Autor

2. Universidade Federal de Uberlândia, Instituto de Biologia, Campus Umuarama, Bloco 2D, 38.400-902 Uberlândia, Minas Gerais, Brasil

3. Autor para correspondência: danilobioufu@gmail.com 
Diamantina (Rapini et al. 2002). Esta região tem uma alta taxa de endemismo para as espécies vegetais devido provavelmente às suas particularidades, principalmente climáticas, não compartilhadas por nenhuma outra região ao seu entorno (Echternacht et al. 2011).

A família Asteraceae (Compositae) possui 1.6001.700 gêneros e 24.000 espécies, sendo a família mais representativa entre as eudicotiledôneas (Funk et al. 2009). No Brasil, a família é representada por 275 gêneros e 2.043 espécies, das quais 1.305 são exclusivas do Brasil (Nakajima et al. 2012a). As Asteraceae são bem distribuídas em regiões com fisionomias montanhosas e savânicas, como as encontradas na Cadeia do Espinhaço (Leitão-Filho \& Semir 1987, Hind 1995; 2003a, b, Hatschbach et al. 2006).

Dentre as Asteraceae, a tribo Heliantheae s.l. diferencia-se por possuir geralmente folhas opostas, receptáculo geralmente paleáceo, flores usualmente amarelas, anteras em sua maioria enegrecidas e pápus geralmente aristados ou escamiformes (Karis \& Ryding 1994). É a terceira maior tribo da família, com 189 gêneros e 2.500 espécies que se distribuem pantropicalmente, em especial no México (Karis \& Ryding 1994). No Brasil, ocupa a quinta posição em número de espécies e está representada por cerca de 380 espécies (das quais 199 espécies restritas ao Brasil) distribuídas em 48 gêneros (Nakajima et al. 2012a).

Apesar da importância e representatividade das Asteraceae, ainda existem poucos estudos realizados em regiões com alta taxa de endemismo como nos campos rupestres, podendo ser citados os levantamentos florísticos de Leitão-Filho \& Semir (1987), Hind (1995, 2003a, b), Nakajima (2000), Hatschbach et al. (2006), Almeida (2008) e Borges et al. (2010).

Os estudos de levantamentos florísticos e de descrições taxonômicas são necessários para conhecer a flora local e traçar planos de conservação efetivos, antes que essas espécies sejam perdidas, por causa das ocorrentes degradações nesses ambientes savânicos e consequente perda das espécies vegetais (Prance et al. 2000).

Dada a importância da Cadeia do Espinhaço, dos campos rupestres e da família Asteraceae para a conservação das espécies, o presente estudo tem por objetivo apresentar o tratamento florístico de Heliantheae s.l. no Parque Estadual do Biribiri, município de Diamantina, Minas Gerais.

\section{Material e métodos}

O Parque Estadual do Biribiri (PEB) está situado na região do alto vale do rio Jequitinhonha, no centro da Cadeia do Espinhaço, denominado Platô de Diamantina (figura 1), compreendido entre as coordenadas $18^{\circ} 14^{\prime} 53^{\prime \prime}-18^{\circ} 02^{\prime} 15^{\prime \prime S}$ e $43^{\circ} 39^{\prime} 57^{\prime \prime}-$ $43^{\circ} 29^{\prime} 36^{\prime \prime} \mathrm{W}$, a $15 \mathrm{~km}$ do centro do município de Diamantina, Estado de Minas Gerais, com uma área de 16.998,66 hectares, abrangendo 4,37\% do município (IEF 2004).

O clima da região caracteriza-se por possuir uma estação chuvosa com temperaturas elevadas e uma estação seca mais fria, com uma temperatura média anual de $18,9^{\circ} \mathrm{C}$ (IEF 2004). O solo predominante da região é o neossolo litólico psamítico típico (RLq), que é raso, pedregoso, com permeabilidade moderada, baixa fertilidade e baixa capacidade de saturação e de retenção de água (IEF 2004).

O Parque possui diferentes formações vegetacionais incluindo áreas florestais e áreas de cerrado (IEF 2004). As fitofisionomias predominantes no PEB são: floresta estacional semidecidual, cerrado típico, cerrado ralo, cerrado rupestre, campo limpo e campo rupestre (IEF 2004).

Os exemplares botânicos analisados foram obtidos por meio de sete viagens de coleta com duração de cinco dias cada, realizadas em um período aproximado de um ano e meio (maio, agosto, outubro e dezembro de 2011, março, junho e setembro de 2012), abrangendo os meses chuvosos e de seca. As localidades de coleta foram definidas de modo a percorrer todo o Parque Estadual do Biribiri onde o acesso era possível por estradas principais, trilhas ou caminhadas aleatórias.

Nas expedições de coleta foram anotadas algumas características dos espécimes, tais como hábito, cor da corola, e as épocas de floração e frutificação. Os espécimes foram fotografados utilizando-se máquina fotográfica digital e as coletas foram georeferenciadas por meio de aparelho de GPS. Os exemplares com flores e/ou frutos foram prensados e secos em estufas de campo por 3 a 7 dias. A montagem e incorporação das exsicatas foram realizadas no Herbarium Uberlandense (HUFU) do Instituto de Biologia da Universidade Federal de Uberlândia, MG. As duplicatas serão doadas para o herbário DIAM e para outros herbários nacionais e estrangeiros com acervo representativo dos campos rupestres (herbários RB, SPF, MBM, BHCB e K, Thyers et al. 2012). 
Além dos exemplares coletados foram analisadas exsicatas provenientes de empréstimos de outros herbários: DIAM (Universidade Federal dos Vales do Jequitinhonha e Mucuri), SPF (Universidade de São Paulo), UEC (Universidade Estadual de Campinas), ESA (Escola Superior de Agricultura "Luiz de Queiroz") e BHCB (Universidade Federal de Minas Gerais). Os acrônimos dos herbários estão de acordo com Thyers et al. (2012).

As identificações foram realizadas e/ou confirmadas utilizando-se a bibliografia taxonômica disponível, bem como por comparação com outras exsicatas incorporadas ao acervo do HUFU ou fotos dos tipos disponíveis nas coleções virtuais dos herbários nacionais e estrangeiros, particularmente de NY, MO, US, K, L, U, W (acrônimos dos herbários de acordo com Thyers et al. 2012), além de consulta aos especialistas, quando necessário.

Neste trabalho optou-se pela classificação de Heliantheae s.l. adotada por Karis \& Ryding (1994). A classificação de Heliantheae é bastante complexa e vem sofrendo grandes alterações no decorrer das décadas, sendo desmembrada em várias tribos distintas, mas ainda em aperfeiçoamento (Panero 2007, Baldwin 2009). Por isso adotou-se nesse trabalho um sistema mais amplo e inclusivo.

As descrições utilizam a terminologia adaptada de Radford (1986) e da bibliografia específica de Asteraceae (Santos 2001, Roque \& Bautista 2008, Funk et al. 2009). Cada uma dessas descrições segue uma padronização das características dentro de cada gênero. Para possibilitar as comparações realizadas entre o número de espécies do PEB e de outras regiões de campo rupestre do Brasil foi utilizada a classificação proposta por Karis \& Ryding (1994), já que alguns trabalhos feitos nessas regiões utilizavam outro tipo de classificação.

O tratamento florístico de Heliantheae s.l. consiste de uma chave de identificação a nível específico, descrição das espécies, seguidas de comentários taxonômicos e materiais examinados. Os comentários taxonômicos trazem distribuição geográfica, ocorrência nas fitofisionomias, épocas de floração/frutificação e características diagnósticas das espécies estudadas.

\section{Resultados e Discussão}

A tribo Heliantheae s.l. no PEB é representada por 16 espécies em nove gêneros. Os gêneros mais representativos foram Calea, com quatro espécies, seguido por Aspilia e Bidens, com três espécies cada. Os outros gêneros, Acanthospermum, Aldama, Cosmos, Dimerostemma, Galinsoga e Melampodium, estão representados com apenas uma espécie cada. Dessas espécies, Calea nitida e C. oxylepis são restritas ao Estado de Minas Gerais, o que corresponde a 12,5\% do total de espécies. Além disso, a espécie Galinsoga parviflora Cav. teve sua distribuição confirmada no presente levantamento para o Estado de Minas Gerais, pois era conhecida apenas como ocorrendo no Estado de São Paulo e sul do Brasil.

Chave para a identificação das espécies de Heliantheae s.l. do Parque Estadual do Biribiri, Diamantina, Estado de Minas Gerais

\section{Lâmina foliar partida}

2. Flores do raio alaranjadas, cipselas rostradas, calículo presente 12. Cosmos sulphureus

2. Flores do raio amarelas, cipselas sem rostro, calículo ausente

3. Pápus 4-aristado, folhas pinatipartidas, 7-9 folíolos, cipselas recurvadas 5. Bidens cynapiifolia

3.Pápus 2 ou 3-aristado, folhas pinatissectas, 3-5 folíolos, cipselas não recurvadas

4. Pápus 2-aristado, flores glabras, folhas com as faces glabras, venação camptódroma ..... 7. Bidens segetum

4. Pápus 3-aristado, flores glandulosas, folhas com as faces tomentosas, venação craspedódroma

6. Bidens pilosa

1. Lâmina foliar inteira

5. Cipselas fusiformes, aristas retrorsas

6. Pápus 2-aristado, flores glabras, folhas com as faces glabras, venação camptódroma 7. Bidens segetum

6. Pápus 3-aristado, flores glandulosas, folhas com as faces tomentosas, venação craspedódroma

5. Cipselas de outras formas, aristas não retrorsas

7. Flores do raio neutras 
8. Invólucro subgloboso envolvido por brácteas subinvolucrais foliáceas, capítulos subradiados, cipselas aladas 13. Dimerostemma brasiliana

8. Invólucro campanulado ou cilíndrico-campanulado não envolvido por brácteas subinvolucrais, capítulos radiados, cipselas desprovidas de alas

9. Folhas alternas, nervação acródroma, brácteas involucrais lanceoladas, flores do raio 8-10-nervadas 16. Aldama bracteata

9. Folhas opostas, nervação craspedódroma ou reticulódroma, brácteas involucrais de outras formas, flores do raio 2-3-nervadas

10. Subarbusto prostrado, folhas elípticas a ovais, nervação reticulódroma, brácteas involucrais foliáceas, cipselas vilosas, pápus paleáceo 4. Aspilia riedelii

10. Subarbusto ereto ou arbusto, folhas lineares a lanceoladas, nervação craspedódroma, brácteas involucrais escariosas, cipselas pubescentes, pápus coroniformes 11. Ramos estrigosos, folha com face abaxial serícea 2. Aspilia foliosa

11. Ramos vilosos, folha com face abaxial lanosa ou estrigosa 3. Aspilia fruticosa

7. Flores do raio pistiladas

12. Brácteas involucrais internas adnatas ao fruto, flores do disco funcionalmente estaminadas, pápus ausente

13. Folhas deltóides, base atenuada, flores alvas, cipselas biformes, obovadas ou lineares, equinadas 1. Acanthospermum australe

13. Folhas rômbicas, base auriculada, flores amarelas, cipselas com forma única, gibosas, lisas 15. Melampodium perfoliatum

12. Brácteas involucrais internas não aderidas ao fruto, flores do disco monóclinas, pápus presente 14. Folhas lanceoladas a deltoides, flores do raio brancas 14. Galinsoga parviflora 14. Folhas de outras formas, flores do raio amarelas

15. Nervação hifódroma ou campilódroma, capítulos solitários ou em dicásios simples, invólucros campanulados, 7 a 12 flores do raio

16. Folhas filiformes, base truncada, nervação hifódroma 8. Calea graminifolia

16. Folhas ovais a elípticas, base arredonda a subcordada, nervação campilódroma 9. Calea myrtifolia

15. Nervação reticulódroma, capítulos dispostos em corimbos, invólucros cilíndricos, 2 flores do raio 17. Folhas com pecíolo 0,78-1,4 cm compr., lâmina foliar 6-6,7 cm compr., elíptica com base cuneada 10. Calea nitida

17. Folhas subsésseis, pecíolo com 0,13-0,15 cm compr., lâmina foliar 3,8-4,2 cm compr., oval com base arredondada 11. Calea oxylepis

\section{Acanthospermum australe (Loefl.) Kuntze, Revis.} Gen. P1. 1: 303. 1891.

Figura $2 \mathrm{a}-\mathrm{b}$

Subarbusto prostrado, 0,3-0,5 m alt.; ramos cilíndricos, estriados, setosos. Folhas inteiras, opostas, pecíolo 0,2-0,7 cm compr., lâmina 2-2,6 $\times$ 0,8-2,6 cm, deltóide, ápice obtuso, margem serreada a crenada, base atenuada, faces estrigosas, glanduloso-pontuadas, nervação acródroma. Capítulos radiados, solitários, pedúnculo 0,3-1,2 cm compr.; invólucro 6,3-7 mm diam., campanulado; receptáculo convexo; páleas oblanceoladas, glabras, ápice truncado; brácteas involucrais 2 séries, foliáceas, esverdeadas, externas 4,7-5 × 2,5-3,3 mm, ovais, setosas, glanduloso-pontuadas, ápice obtuso, internas adnatas ao fruto. Flores do raio 7-10, pistiladas, corola
1,3-1,7 mm compr., liguliforme, branca, estrigosoglandulosa, 3-nervada. Flores do disco 26-28, funcionalmente estaminadas, corola 1,1-1,6 mm compr., infundibuliforme, alva, glandulosa; anteras negras, ápice obtuso, base sagitada; estilete ca. 1,6 mm compr. Cipselas do raio 4,9-5,5 mm compr., obovadas, equinadas, glandulosas; cipselas do disco 1,7-2 mm compr., lineares, lisas, glanduloso-setosas. Pápus ausente.

Material examinado: BRASIL. Minas Gerais: Diamantina, PEB, Estrada para Biribiri, 8-XII-1992, H.F. Leitão-Filho 27.418 (UEC); Alto da Jacuba, $18^{\circ} 08^{\prime} 32,2^{\prime \prime S} 43^{\circ} 36^{\prime} 32,2^{\prime} \mathrm{W}, 1.382$ m.s.m., 14-III-2012, D. Marques et al. 428 (HUFU); São Miguel, $18^{\circ} 08$. 780'S 43³5.252'W, 1.224 m.s.m., 14-XII-2011, D. Marques \& I.M. Araújo 392 (HUFU). 
Espécie nativa da América Tropical, sendo considerada uma planta daninha (Lorenzi 2000). No Brasil a espécie ocorre nos Estados do Pará, Pernambuco, Minas Gerais, São Paulo, Rio de Janeiro, Paraná, Santa Catarina e Rio Grande do Sul (Nakajima et al. 2012a). A espécie foi coletada em campo sujo, área antropizada e na transição entre campo rupestre e mata ciliar, com flores e/ou frutos em março e dezembro. Na revisão feita por Blake (1921) esta espécie é diferenciada das outras espécies pertencentes ao gênero por seus frutos com várias projeções aculeadas em seus ângulos, capítulos pedunculados e frutos obtusos com um orifício no ápice. Segundo Stuessy (1970) o gênero possui afinidades com Melampodium, pois ambos os gêneros possuem as brácteas involucrais internas vascularizadas aderidas ao fruto. No entanto, a espécie
Melampodium perfoliatum que também ocorre no Parque dificilmente pode ser confundida com Acanthospermum, pois apresenta as folhas rômbicas, flores amarelas e cipselas gibosas e lisas (vs. folhas deltóides, flores alvas, cipselas biformes e cipsela radial equinada).

2. Aldama bracteata (Gardner) E.E. Schill. \& Panero, Bot. J. Linn. Soc. 167: 322. 2011. Basiônimo: Viguiera bracteata Gardner, London J. Bot. 7: 404. 1848.

Figura 2 c-e

Subarbusto ereto ou arbusto, 1-1,5 m alt., ramos cilíndricos, estriados, setosos. Folhas inteiras, alternas, sésseis a subsésseis, pecíolo ca. $0,1 \mathrm{~cm}$ compr., lâmina $8,8-10,4 \times 0,2-0,65 \mathrm{~cm}$, linear a lanceolada, ápice agudo-mucronado, margem levemente serreada,

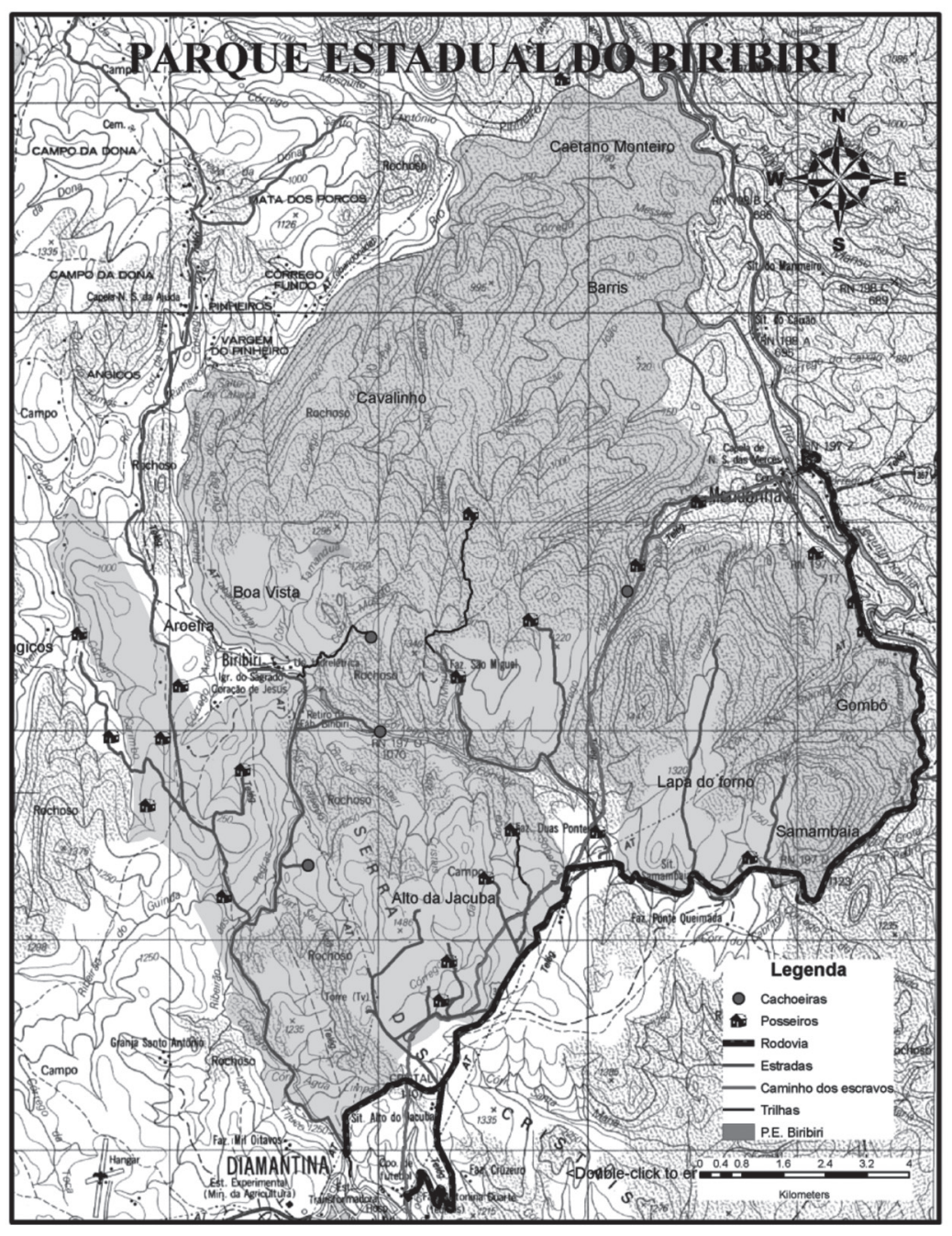

Figura 1: Mapa do Parque Estadual do Biribiri, Diamantina, Minas Gerais, Brasil. Retirado de: IEF 2004.

Figure 1: Map of Parque Estadual do Biribiri, Diamantina, Minas Gerais, Brasil. Taken from: IEF 2004. 
base atenuada, face adaxial estrigosa, face abaxial setosa a estrigosa, nervação acródroma. Capítulos radiados, dispostos em tirsos laxos, pedúnculo 3,3-14,1 cm compr.; invólucro 11,1-18,5 mm diam., campanulado; receptáculo convexo; páleas oblongas, glabras, ápice agudo; brácteas involucrais 4-5 séries, escariosas, marrons, externas 3,3-6,3 × 1,7-2 mm, lanceoladas, setosas, ápice agudo a acuminado, internas 7,5-8,3 × 1,7-4,5 mm, lanceoladas, setosas, ápice acuminado. Flores do raio 9-13, neutras, corola 8,1-19,3 mm compr., liguliforme, amarela, pubescente, 8-10-nervada. Flores do disco 58-70, monóclinas, corola 5-6 mm compr., infundibuliforme, amarela, base setosa; anteras negras, ápice obtuso a agudo, base sagitada; estilete 4,5-5 mm compr. Cipselas 2,5-3 mm compr., obovadas, lisas, setosas. Pápus 3,3-8,3 mm compr., 2-aristado, aristado-paleáceo, dourado.

Material examinado: BRASIL. Minas Gerais: Diamantina, PEB, Próximo à torre de chuva, 23-IV-2004, E.H. Silva \& C.V. Mendonça 21 (HUFU, DIAM); aproximadamente $1 \mathrm{~km}$ da entrada principal

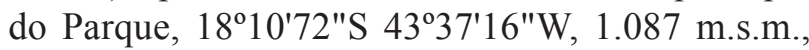
17-V-2011, I.M. Araújo et al. 69 (HUFU); Salto do Mocotó, próximo ao rio Biribiri, $18^{\circ} 08^{\prime} 38,9^{\prime \prime S}$ 4336'44,6"W, 1108 m.s.m., 14-III-2012, D. Marques et al. 422 (HUFU); Buracão, 18²1'17,3"S 4337'45"W, 1.145 m, 26-VI-2012, D. Marques et al. 461 (HUFU).

Aldama bracteata ocorre nos Estados de Goiás e Minas Gerais (Nakajima et al. 2012a), sendo coletada no PEB em campo rupestre, cerrado rupestre e cerrado, às vezes próxima ao curso d'água, com flor e/ou fruto de março a junho. Segundo Magenta \& Pirani (2014) A. bracteata diferencia-se das outras espécies brasileiras de Aldama por suas folhas verde-claras e pelas brácteas involucrais de distintos tamanhos em 4-5(-6) séries. Segundo Magenta (2006) a espécie exibe grande variedade na forma da folha podendo ser lineares ou lanceoladas. Esta espécie pode ser confundida com as do gênero Aspilia, no entanto $A$. bracteata possui folhas alternas e flores do raio 8-10-nervadas enquanto o gênero Aspilia no PEB possui folhas opostas e flores radiais com 2-3-nervadas.

3. Aspilia foliosa (Gardner) Benth. \& Hook., Gen. Pl. 2(1): 372.1867.

Figura 2 f-g

Subarbusto ereto ou arbusto, 0,5-1,5 m alt.; ramos cilíndricos, estriados, estrigosos. Folhas inteiras, opostas, sésseis a subsésseis, pecíolo 0,06-0,09 cm compr., lâmina 2-3,4 × 0,4-0,5 cm, linear a lanceolada, ápice agudo, margem levemente revoluta, base arredondada, face adaxial estrigosa, face abaxial serícea, nervação craspedódroma. Capítulos radiados, solitários ou dispostos em corimbos, pedúnculo 0,37-1,3 cm compr.; invólucro 8,8-13 mm diam., campanulado ou cilíndrico-campanulado; receptáculo levemente convexo; páleas obovadas, glabras, ápice agudo; brácteas involucrais 3-4 séries, adpressas a esquarrosas, escariosas, ápice verde, base marrom, externas 6,3-6,8 × 3-3,3 mm, ovais a elípticas, setosas, ápice obtuso, internas 6-6,3 × 3-3,3 mm, ovais a oblongas, setosas, ápice obtuso. Flores do raio 6-9, neutras, corola 9,8-12,6 mm compr., liguliforme, amarela, glabra, 2-3-nervada. Flores do disco 18-26, monóclinas, corola 6,7-7,6 mm compr., infundibuliforme, amarela, glabra, ápice viloso; anteras negras, ápice obtuso a agudo, base obtusa; estilete 9,7-10,3 mm compr. Cipselas 4,8-5,3 mm compr., obovadas, lisas, pubescentes. Pápus 0,33-0,5 mm compr., coroniforme, enegrecido.

Material examinado: BRASIL. Minas Gerais: Diamantina, PEB, Estrada para Biribiri, 18¹1'59"S 4337'24"W, 1.147 m.s.m., 30-III-2001, J.N. Nakajima \& R. Romero 3086 (HUFU); Antes da descida da Serra do Gombô, 18²10'39,9"S 4332'34,4"W, 1.277 m.s.m., 23-II-2010, I.M. Franco et al. 33 (HUFU); Lapa do Forno, 18 $10^{\circ} 03^{\prime \prime S} 43^{\circ} 32^{\prime} 63^{\prime \prime W}$, 1.300 m.s.m., 19-V-2011 D. Marques et al. 214

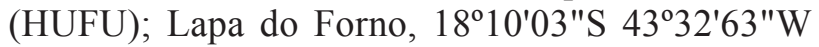
1.300 m.s.m., 19-V-2011, D. Marques et al. 225 (HUFU); Jatobazeiro, 1808'25,4"S 43³4'36,3"W, 1.204 m.s.m., 28-VI-2012, D. Marques et al. 480 (HUFU); Cachoeira da Sentinela, 1809'958"S 4332'309"W, 1.191 m.s.m., 17-IX-2012, D. Marques et al. 492 (HUFU).

A espécie é restrita ao Brasil e ocorre apenas nos Estados de Minas Gerais e Bahia (Nakajima et al. 2012a), e no PEB foi encontrada em campo rupestre, às vezes próxima a cursos d'água. Coletada com flor e frutos em fevereiro, março, maio, junho e setembro. Esta espécie é semelhante à Aspilia fruticosa, que também ocorre no PEB, mas difere apenas pela face foliar dorsal com indumento seríceo, que em A. fruticosa é denso-lanoso (Santos 2001). Além disso, o indumento do ramo também auxilia na diferenciação dessas duas espécies: A. foliosa apresenta ramos estrigosos enquanto $A$. fruticosa possui ramos vilosos.

4. Aspilia fruticosa (Gardner) Baker, Fl. Bras. 6(3): 204. 1884.

Figura $2 \mathrm{f}-\mathrm{g}$ 
Subarbusto ereto ou arbusto, 0,5-2 m alt.; ramos cilíndricos, estriados, vilosos. Folhas inteiras, opostas, sésseis a subsésseis, pecíolo 0,12-0,14 cm compr., lâmina 1,4-9,7 × 0,5-1,8 cm, linear a lanceolada, ápice agudo, margem levemente serreada ou crenadorevoluta, base arredondada, face adaxial estrigosa, face abaxial lanosa, raramente estrigosa, nervação craspedódroma. Capítulos radiados, solitários ou dispostos em corimbos, pedúnculo $0,82-5 \mathrm{~cm}$ compr.; invólucro 6,3-10,4 mm diam., campanulado ou cilíndrico-campanulado; receptáculo levemente convexo; páleas oblongas, lanceoladas, ápice viloso, ápice agudo; brácteas involucrais 3-4 séries, adpressas a esquarrosas, escariosas, ápice verde-enegrecido, base marrom, externas 5,8-6,7 × 3,2-3,3 mm, ovais, setosas, ápice obtuso, internas 7-7,5 × 2,5-3,5 mm, obovadas a oblongas, setosas, ápice agudo. Flores do raio 7-10, neutras, corola 8,4-11,2 mm compr., liguliforme, amarela, glabrescente, 2-3-nervada. Flores do disco 20-31, monóclinas, corola 5,4-6,1 mm compr., infundibuliforme, amarela, ápice viloso; anteras negras, ápice obtuso, base obtusa; estilete 7-7,4 mm compr. Cipselas 4,8-6,3 mm compr., obovadas a oblongas, lisas, pubescentes. Pápus 0,7-0,8 mm compr., coroniforme, amarronzado.

Material examinado: BRASIL. Minas Gerais: Diamantina, PEB, Estrada para Biribiri, $18^{\circ} 10^{\prime} \mathrm{S}$ $43^{\circ} 37^{\prime} \mathrm{W}, 1.098$ m.s.m., 8-IV-1982, N. Hensold CFCR3159; idem, 18-IV-1987, D.C. Zappi et al. s.n (SPF47364); idem, 18 $11^{\circ} \mathrm{S} 43^{\circ} 36^{\prime} \mathrm{W}, 1.200$ m.s.m., 14-II-1991, M.M. Menezes et al. 5.049 (SPF); idem, 8-XII-1992, H.F. Leitão-Filho 27253 (HUFU, UEC); Estrada para Biribiri afloramento rochoso próximo a ponte Ribeirão das Pedras, 8-XII-1997, N. Roque et al. 391 (HUFU); Estrada para Biribiri próximo a Cachoeira da Sentinela, $18^{\circ} 10^{\prime} 56^{\prime \prime S}, 43^{\circ} 37^{\prime} 08^{\prime \prime W}$, 1.200 m.s.m., 28-II-1998, J.R. Pirani et al. 4.031 (SPF, BHCB); Estrada para a Vila do Biribiri antes

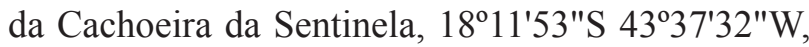
1.221 m.s.m., 23-II-2010, I.M. Franco et al. 24 (HUFU); Trilha para as cachoeiras a $3 \mathrm{~km}$ da entrada, 18¹1'97"S 4337'06"W, 1.175 m.s.m., 18-V-2011, R. Romero et al. 8485 (HUFU); $18^{\circ} 11^{\prime} 97^{\prime \prime S} 43^{\circ} 37^{\prime} 45^{\prime \prime W}$, 1.145 m.s.m., 18-V-2011, D. Marques et al. 200

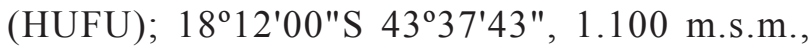
18-V-2011, I.M. Araújo et al. 97 (HUFU); Casa dos Ventos, $18^{\circ} 11.429^{\prime} \mathrm{S} 43^{\circ} 35.896^{\prime} \mathrm{W}, 1.487$ m.s.m., 13-XII-2011, D. Marques et al. 380 (HUFU); São Miguel, $18^{\circ} 11.347^{\prime} \mathrm{S} 43^{\circ} 35.950^{\prime} \mathrm{W}, 1.188$ m.s.m., 14-XII-2011, D. Marques \& I.M. Araújo 386 (HUFU); idem, $18^{\circ} 08.780^{\prime} \mathrm{S} 43^{\circ} 35.252^{\prime \prime} \mathrm{W}, 1.224$ m.s.m., 14-XII-2011, D. Marques \& I.M. Araújo 396 (HUFU); Lavrinha, $18^{\circ} 07.799^{\prime} \mathrm{S} 43^{\circ} 38.595^{\prime} \mathrm{W}, 898$ m.s.m., 15-XII-2011, D. Marques \& I.M. Araújo 406 (HUFU); idem, $18^{\circ} 09.979^{\prime} \mathrm{S} 43^{\circ} 32.650^{\prime} \mathrm{W}, 1.303$ m.s.m., 16-XII-2011, D. Marques \& I.M. Araújo 409 (HUFU); Cachoeira da Sentinela, 1809'04,9"S 43³6'31,7"W, 1.234 m.s.m., 19-IX-2012, D. Marques et al. 497 (HUFU); Cachoeira da Sentinela, $18^{\circ} 09^{\prime} 958^{\prime \prime S}$ 4332'309"W, 1.191 m.s.m., 17-IX-2012, D. Marques et al. 493 (HUFU); Boa Vista, 1807'50,2"S 4336'59,1"W, 1.187 m.s.m., 18-IX-2012, D. Marques et al. 495 (HUFU).

Espécie restrita ao Brasil, A. fruticosa foi encontrada até o momento apenas nos Estados de Minas Gerais e Rio de Janeiro (Nakajima et al. 2012a). Os espécimes foram coletados no Parque em campo rupestre, cerrado sensu stricto, área antropizada e em regiões de transição entre campo rupestre e mata ciliar. Coletada com flor e/ou fruto em fevereiro, abril, maio, setembro e dezembro. Essa espécie é próxima de $A$. jolyana e de A. fruticosa (Santos 2001). Aspilia foliosa é distinta de $A$. jolyana por apresentar brácteas involucrais curtas e eretas (vs. longas e reflexas em A. jolyana) (Santos 2001). As espécies $A$. foliosa e A. fruticosa diferenciam-se pelas características já discutidas no comentário da espécie anterior.

5. Aspilia riedelii Baker, F1. Bras. 6(3): 196. 1884. Figura 2 f-g

Subarbusto prostrado, 0,2-0,6 m alt.; ramos cilíndricos, estriados, setosos a vilosos. Folhas inteiras, opostas, pecíolo 0,3-0,6 cm compr., lâmina 4-5,5 × 1,8-2,8 cm, elíptica a oval, ápice agudo, raramente obtuso, margem levemente serreada, base aguda, raramente atenuada, faces setosas, nervação reticulódroma. Capítulos radiados, solitários, pedúnculo 8,8-19,2 cm compr.; invólucro 16-23,5 mm diam., campanulado; receptáculo levemente convexo; páleas espatuladas, glabras, ápice arredondado; brácteas involucrais 2 séries, esquarrosas, foliáceas, verdes, externas 11-16 × 5,5-8 mm, oval-elípticas, setosas, ápice arredondado a levemente apiculado, internas 9,5-15,3 × 5,8-6,5 mm, oval-elípticas, setosas, ápice arredondado a levemente apiculado. Flores do raio 11-12, neutras, corola 12,4-25 mm compr., liguliforme, amarela, glabra, 2-3-nervada. Flores do disco 35-56, monóclinas, corola 6-7,5 mm compr., infundibuliforme, amarela, pubescente; anteras negras, ápice obtuso, base sagitada ou obtusa; estilete 
7,2-8 mm compr. Cipselas 2-3 mm compr., obcônicas a cilíndricas, lisas, vilosas. Pápus 0,6-1 mm compr., paleáceo, castanho.

Material examinado: BRASIL. Minas Gerais:

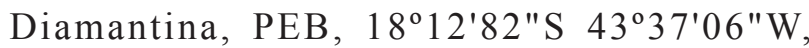
$1.175 \mathrm{~m}$ alt., 17-V-2011, A.R. Rezende et al. 385 (HUFU); Alto da Jacuba, 13-XII-2011, D. Marques et al. 370 (HUFU); Duas Pontes, $18^{\circ} 11.347^{\prime} \mathrm{S} 43^{\circ}$ 35.950'W, 1.249 m.s.m., 14-XII-2011, D. Marques \& I.M. Araújo 382 (HUFU); Lapa do Forno, $18^{\circ} 09.271^{\prime} \mathrm{S}$ 4332.486"W, 1.290 m.s.m., 16-XII-2011, fl., D. Marques \& I.M. Araújo 413 (HUFU).

Aspilia riedelii ocorre nos Estados do Ceará, Bahia, Goiás, Minas Gerais, São Paulo e Rio de Janeiro (Nakajima et al. 2012a). No Parque, A. riedelii ocorre em campo rupestre e campo sujo. Coletada com flor e/ou fruto em maio e dezembro. Segundo Santos (2001) essa espécie tem afinidades com $A$. reflexa que não ocorre no Parque. Aspilia riedelli diferencia-se por apresentar pecíolo e margem levemente dentada, enquanto $A$. reflexa apresenta folhas sésseis e folhas conspicuamente dentadas. A espécie é prontamente diferenciada das outras espécies de Aspilia do PEB pelo seu hábito prostrado, folhas elípticas a ovais, brácteas involucrais foliáceas e em duas séries, cipselas vilosas e pápus paleáceo.

6. Bidens cynapiifolia Kunth, Nov. Gen. Sp. (folio ed.) 4: 185.1820.

Figura $2 \mathrm{~h}$

Subarbusto ereto, 0,4 $\mathrm{m}$ alt.; ramos cilíndricos, estriados, glabrescentes. Folhas pinatipartidas, 7-9 folíolos, opostas, pecíolo 0,35-0,8 cm compr., lâmina 2-3,5 × 1,7-1,9 cm, oval, ápice agudo a acuminado, margem serreada, base atenuada, faces esparsamente vilosas, nervação craspedódroma. Capítulos radiados dispostos em panículas laxas, pedúnculo 14-24,8 cm compr.; invólucro 7-11,5 mm diam., campanulado; brácteas involucrais 2 séries, foliáceas, verdes ou marrons, ápice vináceo, externas ca. $0,8 \times 3 \mathrm{~mm}$, lineares, tomentoso-glandulares, ápice apiculado, internas $6,7 \times 1,5 \mathrm{~mm}$, lanceoladas, pubescentes, ápice apiculado; receptáculo plano; páleas lineares, glandulosas, ápice agudo. Flores do raio ca. 9, neutras, liguliformes, corola 9,7-10,5 mm compr., amarela, glandulosa, 7-nervada. Flores do disco 35-38, monóclinas, corola 5,6-6,5 mm compr., infundibuliforme, amarela, glandulosa; anteras negras, ápice agudo ou obtuso, base obtusa; estilete 5,2-6,4 mm compr. Cipselas 8,7-10,5 mm compr., fusiformes, recurvadas, lisas, glabras. Pápus 2,1-3 mm compr., 4-aristado, aristas retrorsas, castanhas.

Material examinado: BRASIL. Minas Gerais: Diamantina, PEB, 1809'26"S 4336'57"W, 15-II-2001, J.A. Lombardi 4327 (BHCB); trilha próxima a portaria do Parque, $18^{\circ} 13^{\prime} 01,5^{\prime \prime S} 43^{\circ} 36^{\prime} 11,4^{\prime \prime} \mathrm{W}, 1.279$ m.s.m., 25-IV-2012, I.M. Franco et al. 960 (HUFU).

A espécie ocorre nos Estados de Roraima, Amapá, Pará, Amazonas, Tocantins, Acre, Rondônia, Maranhão, Ceará, Rio Grande do Norte, Pernambuco, Mato Grosso, Goiás e Minas Gerais (Nakajima et al. 2012a). De acordo com Sherff (1937) a espécie pode ser distinta das outras espécies de Bidens que ocorrem na América do Sul por possuir as cipselas recurvadas e quatro aristas. Além dessas características, esta espécie diferencia-se das outras espécies de Bidens do PEB por possuir as folhas pinatipartidas.

7. Bidens pilosa L., Sp. Pl. 2: 832. 1753.

Figura $2 \mathrm{i}$

Subarbusto ereto, 0,2-0,6 m alt.; ramos cilíndricos, estriados, glabrescentes. Folhas inteiras ou pinatissectas, 3-5 folíolos, opostas, pecíolo 1,2-2,1 cm compr., lâmina $2-5 \times 0,8-2,8 \mathrm{~cm}$, oval, ápice agudo a acuminado, margem levemente serreada, base atenuada, faces esparsamente tomentosas, nervação craspedódroma. Capítulos radiados, dispostos em panículas laxas, pedúnculo 2,8-4,8 cm compr.; invólucro 4-7 mm diam., campanulado; receptáculo plano; páleas linear-lanceoladas, glabras, ápice acuminado; brácteas involucrais 2-3 séries, foliáceas, verdes ou marrons, externas 3-3,7 $\times 0,5-0,8 \mathrm{~mm}$, oblongas, tomentosas, ápice apiculado, internas 4,2-5 × 0,5-0,6 mm, linear-lanceoladas, glabras, ápice obtuso. Flores do raio 5-6, neutras, corola 6-6,7 mm compr., liguliforme, amarela, glandulosa, 5-nervada. Flores do disco 37-40, monóclinas, corola 3,3-4,2 mm compr., infundibuliforme, amarela, glandulosa; anteras negras, ápice agudo a obtuso, base sagitada a obtusa; estilete 3,4-3,9 mm compr. Cipselas 3,1-4,1 mm compr., fusiformes, lisas, ápice viloso. Pápus 2,2-3 mm compr., 3-aristado, aristas retrorsas, amarronzadas.

Material examinado: BRASIL. Minas Gerais: Diamantina, PEB, Córrego da Roda, $18^{\circ} 10.902^{\prime} \mathrm{S}$ 34.891'W, 1.306 m.s.m., 23-VIII-2011, I.M. Araújo et al. 127 (HUFU); Alto da Guinda, 18 ${ }^{\circ} 10.364^{\prime} \mathrm{S}$ 4338.048'W, 1.291 m.s.m., 15-XII-2011, I.M. Araújo \& D. Marques 398 (HUFU); São Miguel, 1808'780"S 4335'252"W, 1.224 m.s.m., 14-XII-2012, D. Marques \& I.M. Araújo 393 (HUFU). 
Bidens pilosa é uma espécie subespontânea originária da América Tropical (Lorenzi 2000) que tem registro de coletas para quase todos Estados do Brasil, exceto Acre, Rondônia, Roraima e Amapá (Nakajima et al. 2012a). Segundo Sherff (1937) essa espécie possui uma grande variação morfológica podendo ser confundida com diversas espécies de Bidens. No entanto, pode ser diferenciada das outras espécies do gênero que ocorrem na América do Sul pelas seguintes características: erva anual, hábito ereto, folha inteira ou dividida, brácteas involucrais externas com o ápice dilatado, capítulos radiados e cipselas com mais de duas aristas (Sherff 1937). Bidens pilosa é distinta das outras espécies de Bidens que ocorrem no PEB pela presença de venação craspedódroma e pápus com 3 aristas. Outras características, em conjunto, podem auxiliar na identificação da espécie como suas folhas inteiras ou pinatissectas com 3-5 folíolos com ambas as faces tomentosas, flores glandulosas e cipselas com o ápice viloso.

8. Bidens segetum Mart. ex Colla, Her. Pedem. 3: 307. 1834.

Figuras $2 \mathrm{j}$

Arbusto, ca. 1,5 m alt.; ramos cilíndricos, estriados, glabros. Folhas inteiras ou raramente pinatissectas, 3 folíolos, opostas, pecíolo 1,3-2,6 cm compr., lâmina 3-6,6 × 0,8-2,2 cm, lanceolada, ápice acuminado, margem levemente serrilhada, base atenuada, faces glabras, nervação camptódroma. Capítulos radiados, dispostos em panículas laxas, pedúnculo 0,5-2,3 cm compr.; invólucro 7,9-8,6 mm diam., campanulado; receptáculo plano; páleas oblongas a lanceoladas, glabras, ápice obtuso a agudo; brácteas involucrais 2 séries, foliáceas, verde-enegrecidas, externas 4,9-6,4 × 0,9-1,1 mm, linear-lanceoladas, glabras, ápice obtuso, internas 7,2-7,3 × 1,1-1,4 mm, linear-lanceoladas, glabras, ápice obtuso. Flores do raio 5-6, neutras, corola 13-14,7 mm compr., liguliforme, amarela, glabra, 9-10-nervada. Flores do disco 11-16, monóclinas, corola 5,5-6 mm compr., infundibuliforme, amarela, glabra; anteras marrons, ápice agudo, base sagitada; estilete 7,9-8,8 $\mathrm{mm}$ compr. Cipselas 6,4-7,4 mm compr., fusiformes, lisas, bordas laterais vilosas. Pápus 4,8-5,1 mm compr., 2-aristado, aristas retrorsas, amarronzadas.

Material examinado: BRASIL. Minas Gerais: Diamantina, PEB, Alto da Jacuba, próxima a Antena, 18¹2'10,6"S 4336'12,4"W, 1.449 m.s.m., 23-IV-2012, I.M. Franco \& M.M. Cota 909 (HUFU).
Bidens segetum ocorre no Distrito Federal e nos Estados da Bahia, Goiás, Minas Gerais, Rio de Janeiro, São Paulo, Paraná e Santa Catarina (Nakajima et al. 2012a). A espécie foi coletada em campo sujo próxima a uma área antropizada, com flor e fruto em abril. Na revisão do gênero (Sherff 1937) nota-se a difícil distinção entre $B$. segetum, B. rubifolia e $B$. squarrosa, sendo necessários estudos adicionais para a compreensão das delimitações taxonômicas. No entanto, a espécie pode ser reconhecida pelas seguintes características em conjunto: arbusto perene escandente, folha inteira ou dividida, geralmente lanceolada, brácteas involucrais exteriores em número de 7 a 9, cipselas com 8 a $13 \mathrm{~mm}$ de comprimento e ciliadas (Sherff 1937). Esta espécie pode ser distinguida das demais espécies do gênero encontradas no Parque pelo seguinte conjunto de características: folhas geralmente inteira ou pinatissecta com 3 folíolos, venação camptódroma e pápus 2-aristado.

9. Calea graminifolia Sch. Bip. ex Krasch., Bot. Mater. Gerb. Glavn. Bot. Sada R. S. F. S. R. 4: 53. 1923.

Figura 3 a-b

Erva, 0,2-0,3 $\mathrm{m}$ alt.; ramos cilíndricos, estriados, glandulosos. Folhas inteiras, opostas, sésseis, lâmina 4,2-5,9 $\times 0,12-0,16 \mathrm{~cm}$, filiforme, ápice obtuso, margem levemente denteada, base truncada, faces glabras, raramente setosas, pontuações translúcidas, nervação hifódroma. Capítulos radiados, solitários, pedúnculo 14,4-19,6 cm compr.; invólucro 8,5-14,4 mm diam., campanulado; receptáculo convexo; páleas lanceoladas, glabras, ápice longamente acuminado; brácteas involucrais 2-3 séries, foliáceas, castanhas, externas 5,8-6,3 × 1,3-2 mm, oval-lanceoladas, margem setosa, ápice obtuso, internas 8,5-10 × 3,3-3,8 mm, oblongas, glabras, ápice arredondado. Flores do raio $7-10$, pistiladas, corola 14,2-16 $\mathrm{mm}$ compr., liguliforme, amarela, glabra, 4-5- nervada. Flores do disco 13-17, monóclinas, corola 5,8-6,3 mm compr., infundibuliforme, amarela, glabra; anteras amarelas, ápice obtuso, base sagitada; estilete 4,2-5,8 mm compr. Cipselas 4,2-5 mm compr., prismáticas, lisas, costas setosas. Pápus 2,5-3,8 mm compr., paleáceo, creme.

Material examinado: BRASIL. Minas Gerais: Diamantina, PEB, Estrada para Biribiri, 22-XI-1985, J.R. Pirani et al. s.n. (SPF40204, BHCB83907); Nascente da água Limpa, $18^{\circ} 12^{\prime} .598^{\prime \prime S} 43^{\circ} 36.123^{\prime} \mathrm{W}$, 1.394 m.s.m., 13-XII-2011, D. Marques et al. 374 (HUFU); Vargem da Santa Polonha, 14-XII-2011, D. Marques \& I.M. Araújo 388 (HUFU). 

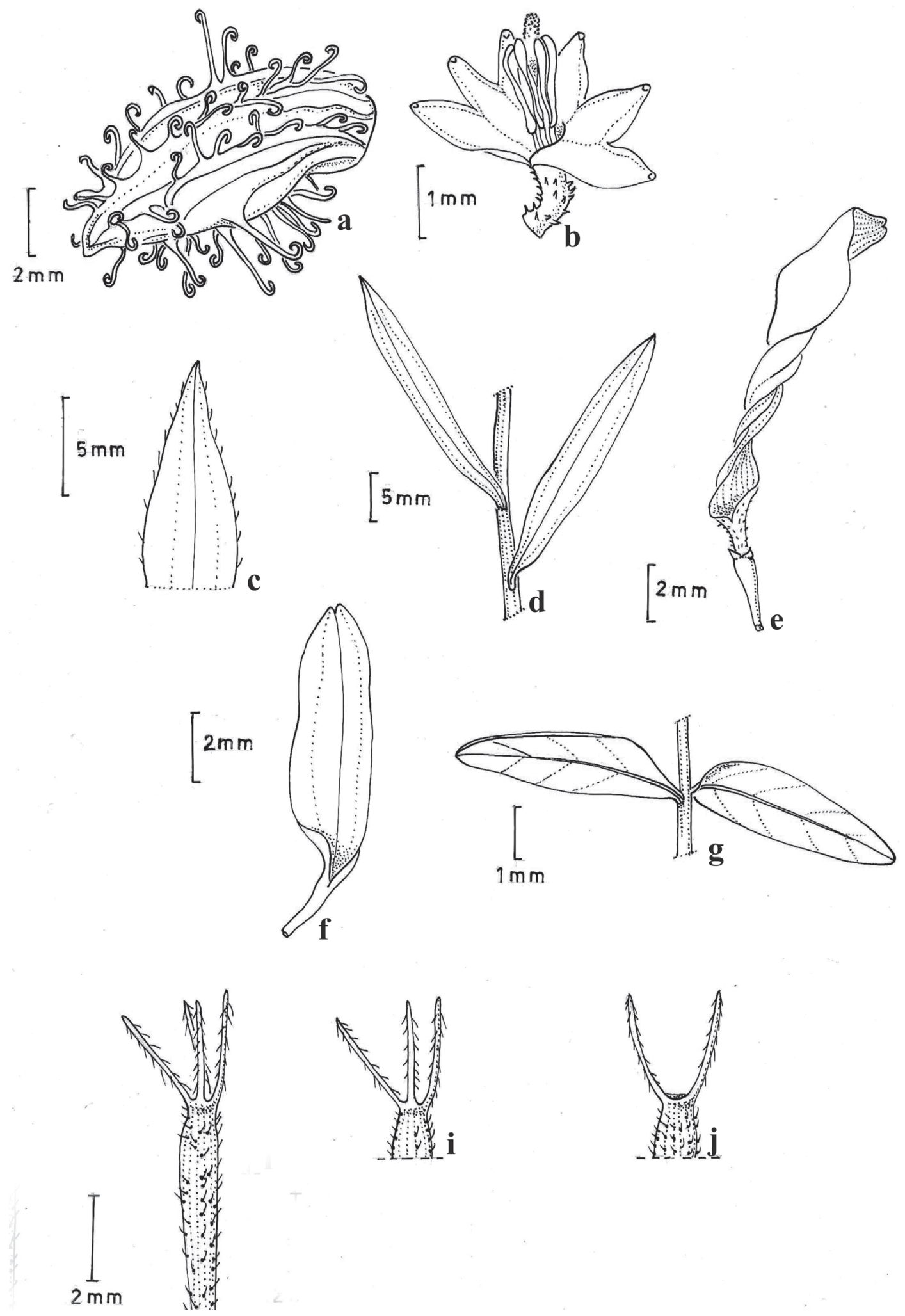

Figura 2: Representação esquemática dos gêneros de Heliantheae s.l. do Parque Estadual do Biribiri. a-b. Acanthospermum. a. Cipsela equinada. b. Detalhe da flor aberta. c-e. Aldama. c. Bráctea involucral. d. Folhas alternas. e. Flor do raio. f-g. Aspilia. f. Flor do raio. g. Folhas opostas. h-j. Bidens. h. Pápus 4-aristado. i. Pápus 3-aristado. j. Pápus 2-aristado.

Figure 2: Schematic representation of the genera of Heliantheae s.l. from Parque Estadual do Biribiri. a-b. Acanthospermum. a. Equinate cypsela. b. Detail of open floret. c-e. Aldama. c. Involucral bract. d. Alternate leaves. e. Ray floret. f-g. Aspilia. f. Ray floret. g. Opposite leaves. h-j. Bidens. h. Pappus of 4 aristate. i. Pappus of 3 aristate. j. Pappus of 2 aristate. 
Calea graminifolia ocorre apenas nos Estados de Minas Gerais e São Paulo (Nakajima et al. 2012a). A espécie ocorre em áreas de campo rupestre normalmente com solo alagado. Foi coletada com flor e/ou fruto em novembro e dezembro. De acordo com Pruski (1998) C. graminifolia forma um grupo de espécies próximas com C. coronopifolia Sch. Bip. ex Krasch., C. kirkbridei H. Rob., C. nematophylla Pruski e C. tridactylita Sch. Bip. ex Krasch. por apresentarem hábito, folhas e pápus similares. As folhas filiformes, opostas e verdes fazem com que $C$. graminifolia assemelhe-se mais a C. nematophylla (Pruski 1998), mas C. graminifolia ocorre no Brasil (vs. Bolívia), possui capítulos solitários (vs. cimeiras) e limbo das flores do raio oblanceolado (vs. obovado) (Pruski 1998). Essa espécie é prontamente diferenciada das outras espécies de Calea que ocorrem no PEB por apresentar em conjunto, folhas filiformes, glabras, base truncada, nervação hifódroma e invólucro com $8,5-14,4 \mathrm{~mm}$ diam.

10. Calea myrtifolia (DC.) Baker, Fl. Bras. 6(3): 260. 1884.

Figura 3 a-b

Arbusto a arvoreta, 1-2 m alt.; ramos cilíndricos, estriados, puberulentos a escamiformes. Folhas inteiras, opostas, sésseis a subsésseis, pecíolo 0,1-0,2 cm compr., lâmina 1,2-4,7 × 0,7-3,4 cm, oval a elíptica, ápice obtuso, margem levemente revoluta, base arredondada a subcordada, faces glandulosas, nervação campilódroma. Capítulos radiados, solitários ou dispostos em dicásios simples, pedúnculo 2,2-4,6 cm compr.; invólucro 12,4-16,4 mm diam., campanulado; receptáculo convexo; páleas lanceoladas, glabras, ápice longamente acuminado; brácteas involucrais 3-4 séries, foliáceas, castanhas, externas 5-5,8 × 3,3-4,2 mm, ovais, glabras, ápice arredondado, internas 8,3-9,2 × 3,3-5,3 mm, glabras, oblongas, ápice longamente acuminados. Flores do raio $10-12$, pistiladas, corola $11-11,7 \mathrm{~mm}$ compr., liguliforme, amarela, glabra, 4-6-nervada. Flores do disco 34-60, monóclinas, corola 5,3-6 mm compr., infundibuliforme, amarela, glabra; anteras amarelas, ápice agudo, base sagitada; estilete 5,8-7 mm compr. Cipselas 2,5-3,3 mm compr., prismáticas, lisas, costas vilosas. Pápus 0,83-1,5 cm compr., paleáceo, creme.

Material examinado: BRASIL. Minas Gerais: Diamantina, PEB, Estrada para Biribiri, 22-XI-1985, J.R. Pirani et al. s.n., (SPF40210, BHCB83906); Córrego da Roda, $18^{\circ} 10.902^{\prime} \mathrm{S} 43^{\circ} 34.891^{\prime \prime}$,
1.306 m.s.m., 23-VIII-2011, I.M. Araújo \& D. Marques 116 (HUFU); Sítio do Valtinho, 1809'379"S 4335'778"W, 24-VIII-2011, D. Marques \& I.M. Araújo 225 (HUFU); Nascente da água Limpa 18².568'S 43ํ 36.123"W, 1.394 m.s.m., 13-XII-2011, D. Marques et al. 372 (HUFU); Alto da Mãe Rita atrás da Casa dos Ventos, $18^{\circ} 11^{\prime} 0,7^{\prime \prime}$ S 4336'4,5"W, 1.396 m.s.m., 27-VI-2012, D. Marques et al. 498 (HUFU).

Calea myrtifolia ocorre nos Estados de Minas Gerais, São Paulo, Santa Catarina e Paraná (Nakajima et al.2012a). A espécie foi coletada em áreas de cerrado sensu stricto, campo rupestre, campo limpo, quase sempre perto de cursos d'água ou solos alagados, com flor e fruto em junho, agosto, novembro e dezembro. Calea myrtifolia, segundo Pruski \& Urbatsch (1998), diferencia-se das outras Calea do complexo Calea myrtifolia por possuir folhas opostas, ovais ou elípticas, inteiras, nervação campilódroma e cipsela vilosa. A espécie assemelha-se a C. phyllolepis, porém C. myrtifolia possui as folhas com margem inteira (vs. margem serreada) (Pruski \& Urbatsch 1998). No PEB C. myrtifolia é prontamente diferenciada das outras Calea por apresentar em conjunto, folhas ovais com base arredondada a subcordada, nervação campilódroma, inflorescência em dicásios simples ou solitários, invólucro com 12,4-16,4 mm diam. e 10 ou mais flores do raio.

11. Calea nitida Less., Linnaea 5(1): 158. 1830. Figura 3 c-d

Subarbusto ereto ou arbusto, 1,3-1,8 m alt.; ramos cilíndricos, estriados, glanduloso-puberulentos. Folhas inteiras, opostas, pecíolo 0,78-1,4 cm compr., lâmina 6-6,7 × 3,2-3,6 cm, elíptica, ápice obtuso a agudo, margem crenada-serreada, base cuneada, face adaxial estrigosa, face abaxial setoso-glandulosa, nervação reticulódroma. Capítulos radiados, dispostos em corimbos, pedúnculo $0,2-0,3 \mathrm{~cm}$ compr.; invólucro 1,9-2,3 mm diam., cilíndrico; receptáculo convexo; páleas ovais, glandulosas, ápice arredondado; brácteas involucrais 3-4 séries, foliáceas, castanhas, externas 2,2-2,7 × 1-1,5 mm, ovais, margem vilosa, ápice arredondado, internas 5,2-6 × 2-2,7 mm, elípticas, margem vilosa, ápice agudo a obtuso. Flores do raio 2, pistiladas, corola 4,5-5,2 $\mathrm{mm}$, liguliforme, compr., amarela, glandulosa, 5-nervada. Flores do disco 2-3, monóclinas, corola 4,16-6,3 mm compr., infundibuliforme, amarela, glandulosa; anteras amarelo-amarronzadas, ápice obtuso, base sagitada; estilete 5,3-8 mm compr. Cipselas 4,4-5,3 mm compr., 
prismáticas, lisas, setosas. Pápus 1,5-2,7 mm compr., paleáceo, dourado.

Material examinado: BRASIL. Minas Gerais: Diamantina, PEB, São Miguel- Trilha dentro da mata, 1.260 m.s.m., 15-IV-2005, E.H. Silva \& C.V. Mendonça 317 (DIAM, BHCB); Alto do Mocotó, próximo ao rio Biribiri, $18^{\circ} 08^{\prime} 42,1^{\prime \prime S} 43^{\circ} 36^{\prime} 53,8^{\prime \prime} \mathrm{W}$, 1.033 m.s.m., 13-III-2012, D. Marques et al. 420 (HUFU).

Espécie restrita ao Estado de Minas Gerais (Nakajima et al. 2012a). No Parque, ocorre em cerrado sensu stricto e campo rupestre, e coletada com flor e fruto em março e abril. Juntamente com $C$. oxylepis, $C$. nitida faz parte da seção Lemmatium (Urbatsch et al. 1986). Calea nitida diferencia-se das outras espécies dessa seção por apresentar capítulos radiados, pápus livre, ápice das brácteas involucrais eretas, folhas com pecíolo evidente e base da lâmina cuneada (Urbatsch et al. 1986). Entre as espécies de Calea que ocorrem no Parque, $C$. nitida está mais relacionada com $C$. oxylepis por ambas apresentarem nervação reticulada, capítulos cilíndricos em corimbos, 2 flores do raio, invólucro com até $3,1 \mathrm{~mm}$ diam. Porém, $C$. nitida difere desta por ter maior comprimento do pecíolo e da folha, folhas elípticas com base cuneada, face adaxial foliar estrigosa e abaxial setosa-glandulosa.

12. Calea oxylepis Baker, Fl. Bras. 6(3): 254. 1884. Figura $3 \mathrm{c}-\mathrm{d}$

Subarbusto ereto ou arbusto, 0,6-1 m alt., ramos cilíndricos, estriados, puberulento-vilosos. Folhas inteiras, opostas, subsésseis, pecíolo 0,13-0,15 cm compr., lâmina 3,8-4,2 × 2,6-3,2 cm, oval, ápice agudo ou arredondado, margem serreada, base arredondada, às vezes atenuada, faces glandulosas, nervação reticulódroma. Capítulos radiados, dispostos em corimbos, pedúnculo $0,5-1,5 \mathrm{~cm}$ compr.; invólucro 3-3,1 mm diam., cilíndrico; receptáculo convexo; páleas elípticas, glandulosas, ápice arredondado; brácteas involucrais 3-4 séries, foliáceas, castanhas, externas 2,9-5,8 × 2,5-3 mm, ovais, glandulosas, margem vilosa, ápice obtuso, internas 7-10,5 × 2-2,3 mm, elípticas, glandulosas, margem vilosa, ápice obtuso. Flores do raio 2, pistiladas, corola 5,6-6,5 $\mathrm{mm}$ compr., liguliforme, amarela, face externa glandulosa, 5-6-nervada. Flores do disco 3-4, monóclinas, corola 5,8-6,4 mm compr., infundibuliforme, amarela, glabra; anteras amarelas, ápice obtuso, base sagitada; estilete 5,7-7,5 mm compr. Cipselas 6,1-7,7 mm compr., prismáticas, lisas, costas setosas. Pápus 2,4-3,5 mm compr., paleáceo, bege.
Material examinado: BRASIL. Minas Gerais: Diamantina, PEB, Próximo à torre de celular, 23-IV-2004, E.H. Silva \& C.V. Mendonça 51 (BHCB); Arredores da Casa dos Ventos, 18 11'10,7"S 4336'2,4"W, 1.419 m.s.m., 14-III-2012, D. Marques 440 (HUFU).

Espécie restrita ao Estado de Minas Gerais (Nakajima et al. 2012a). No Parque, C. oxylepis foi coletada em cerrado sensu stricto e campo rupestre com flor e fruto em março e abril. Segundo Urbatsch et al. (1986) C. oxylepis é distinta das outras espécie de Calea da seção Lemmatium por apresentar capítulos radiados, pápus livre e folhas sésseis ou subsésseis com um pecíolo menor que $3 \mathrm{~mm}$ de comprimento. Calea oxylepsis é distinta de todas as outras Calea do Parque por apresentar folhas ovais com base arredondada, nervação reticulada, pecíolos inconspícuos e folhas com faces glandulosas, 2 flores do raio e capítulos cilíndricos em corimbos.

13. Cosmos sulphureus Cav., Icon. 1(3): 56, pl. 79. 1791. Basiônimo: Bidens sulphurea (Cav.) Sch. Bip., Bot. Voy. Herald 308. 1856.

Figura 3 e-f

Erva, 0,2 m alt.; ramos cilíndricos, estriados, glabrescentes. Folhas pinatipartidas, 5-9 folíolos, opostas, pecíolo 1,1-2 cm compr., lâmina 3-4,5 × 2,5-3 cm, oval, ápice acuminado, margem serreada, base atenuada, faces glabras, nervação craspedódroma. Capítulos radiados dispostos em dicásios laxos, pedúnculo 4,6-14,2 cm compr.; invólucro 11-17 mm diam., campanulado; receptáculo plano; páleas oblongas, glabras, ápice agudo; calículo verde; brácteas involucrais 2 séries, foliáceas, amarronzadas, externas ca. 6,7-8,2 × 1,1-1,7 mm, lineares ou linear-lanceoladas, ápice agudo, glabras, internas 8,1 $\times 9,7 \mathrm{~mm}$, elípticas, ápice obtuso, glabras. Flores do raio ca. 8 , neutras, corola $16,5-17 \mathrm{~mm}$ compr., liguliforme, alaranjada, glabrescente, 3-nervada. Flores do disco 25-32, monóclinas, corola 7,5-8,3 mm compr., infundibuliforme, amarelo-alaranjada, glabra; anteras marrons, ápice agudo ou retuso, base sagitada; estilete 8,5-9,2 mm compr. Cipselas 7,3-10,1 mm compr., fusiformes, rostradas, lisas, puberulentas. Pápus 3,8-4,4 mm compr., 2-aristado, aristas retrorsas, beges.

Material examinado: BRASIL. Minas Gerais: Diamantina, Mendanha, PEB, Córrego do Marimbeiro,

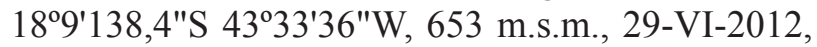
D. Marques et al. 486 (HUFU). 
A espécie subespontânea é originária do México (Lorenzi 2000) e ocorre em todos os Estados brasileiros, exceto Amazônia (Nakajima et al. 2012a). No PEB foi coletada em áreas antropizadas. No Brasil ocorrem três espécies de Cosmos: C. bipinnatus Cav., C. caudatus Kunth. e C. sulphureus Cav. (Nakajima et al. 2012a). Sherff (1932) diferencia C. sulphureus das outras duas espécies brasileiras por suas flores do raio alaranjadas ou muito amareladas. Cosmos sulphureus é próxima das espécies de Bidens por possuir cipselas fusiformes, aristas retrorsas e flores do raio neutras. No entanto, diferencia-se facilmente por apresentar calículo, flores do raio alaranjadas e cipselas rostradas.

14. Dimerostemma brasilianum Cass., Bull. Soc. Philom. Paris 58. 1818. Figura 3 g-i

Subarbusto ereto, $0,4 \mathrm{~m}$ alt.; ramos cilíndricos, estriados, viloso-glandulosos. Folhas inteiras, opostas, pecíolo 0,22-0,37 cm compr., lâmina 2,8-3,2 × 2,6-3 cm, cordiformes, às vezes ovais, ápice agudo, margem levemente crenado-serreada, base subcordada, faces glanduloso-vilosas, nervação acródroma. Capítulos subradiados solitários, pedúnculo 5,5-7,8 cm compr.; invólucro 8,3-11,1 mm diam., subgloboso, envolvido por brácteas subinvolucrais foliáceas; receptáculo plano; páleas ovais, ápice glabro, apiculado; brácteas involucrais 3-4 séries, escariosas, marrons, externas 4-4,5 × 1,5-3,2 mm, ovais a oblongas, vilosas, ápice apiculado ou obtuso, internas 3,7-6 × 1,2-1,4 mm, oblongas, glabras, ápice apiculado. Flores do raio, 4-5, neutras, corola 4,3-5 mm compr., liguliforme em transição para tubulosa, amarela, glandulosa, 3-nervada. Flores do disco 28-36, monóclinas, corola 4,5-4,8 mm compr., infundibuliforme, amarela, pubescente; anteras negras, ápice agudo, base sagitada; estilete 6-7,5 mm compr. Cipselas 2,5-3 mm compr., ovais, lisas, glabras, aladas. Pápus 5-6 mm compr., 2-aristado, bege.

Material examinado: BRASIL. Minas Gerais: Diamantina, PEB, Alto da Jacuba, $18^{\circ} 08^{\prime} 32,2^{\prime \prime S}$ 4336'32,2"W, 1.382 m.s.m., 14-III-2011, D. Marques et al. 426 (HUFU).

A espécie ocorre apenas no Distrito Federal e nos Estados de Goiás, Mato Grosso do Sul, Minas Gerais e São Paulo (Nakajima et al. 2012a). No Parque, foi coletada em campo sujo com flor e fruto em março. Segundo Moraes \& Semir (2009) a espécie diferencia-se das outras Dimerostemma brasileiras por não possuir flores do raio ou quando presentes as flores radiais são pequenas e em transição para flores tubulosas. Essa diferença nas flores do raio aproxima D. brasilianum de D. retifolium (Baker) S.F. Blake. No entanto, D. brasilianum apresenta folhas geralmente opostas (vs. alternas), subcartáceas (vs. coriáceas) e base foliar arredondada, truncada ou subcordada (vs. cuneada) (Moraes \& Semir 2009). No PEB, Dimerostemma brasilianum é facilmente reconhecida por possuir invólucro subgloboso envolvido por brácteas foliáceas, capítulos subradiados, flores do raio em transição para forma tubulosa e cipselas aladas.

15. Galinsoga parviflora Cav., Icon. 3(2): 41-42, pl. 281. 1794.

Figura $3 \mathrm{j}$

Erva prostrada, ca. 0,2 $\mathrm{m}$ alt.; ramos cilíndricos, estriados, estrigosos. Folhas inteiras, opostas, pecíolo ca. 0,3-0,5 cm compr., lâmina 1,4-2 × 1-1,2 cm, lanceolada a deltóide, ápice agudo, margem levemente denteada, base atenuada, faces glanduloso-estrigosas, nervação acródroma. Capítulos radiados, dispostos em dicásios laxos, pedúnculo 0,6-2,4 cm compr.; invólucro 3,8-5,3 mm diam., campanulado; receptáculo convexo; páleas lanceoladas, glabras, ápice agudo; brácteas involucrais 2 séries, foliáceas, esverdeadas, externas ca. 1,7 × $1 \mathrm{~mm}$, elípticas, glabras, ápice obtuso, internas ca. 3,4 × 1,7 mm, ovais, glabras, ápice agudo. Flores do raio 7, pistiladas, corola 2-2,5 mm compr., liguliforme, branca, glabra, 4-nervada. Flores do disco 21, monóclinas, corola 0,8-1,3 mm compr., infundibuliforme, amarela, setosa; anteras marrons, ápice obtuso, base obtusa; estilete ca. 1,7 mm compr. Cipselas ca. 1,5 mm compr., obovadas, lisas, setosoglandulosas. Pápus ca. 1,5 mm compr., paleáceo, bege.

Material examinado: BRASIL. Minas Gerais: Diamantina, PEB, São Miguel, $18^{\circ} 08.780^{\prime} \mathrm{S}$ 4335.252'W, 1.224 m.s.m., 14-XII-2011, D. Marques \& I.M. Araújo 394 (HUFU).

Espécie de origem subespontânea nativa da costa oeste da América do Sul (Lorenzi 2000). No PEB foi encontrada em áreas antropizadas, com flor e fruto em dezembro. De acordo com Nakajima et al. (2012a), ocorre nos Estados do Paraná, Santa Catarina, Rio Grande do Sul e São Paulo, mas o presente levantamento bem como o de Almeida (2008), relataram a espécie para o Estado de Minas Gerais. Galinsoga parviflora é similar a Galinsonga quadriradiata Ruiz \& Pav. que também ocorre no Brasil (Canne 1977). Porém, G. parviflora é 

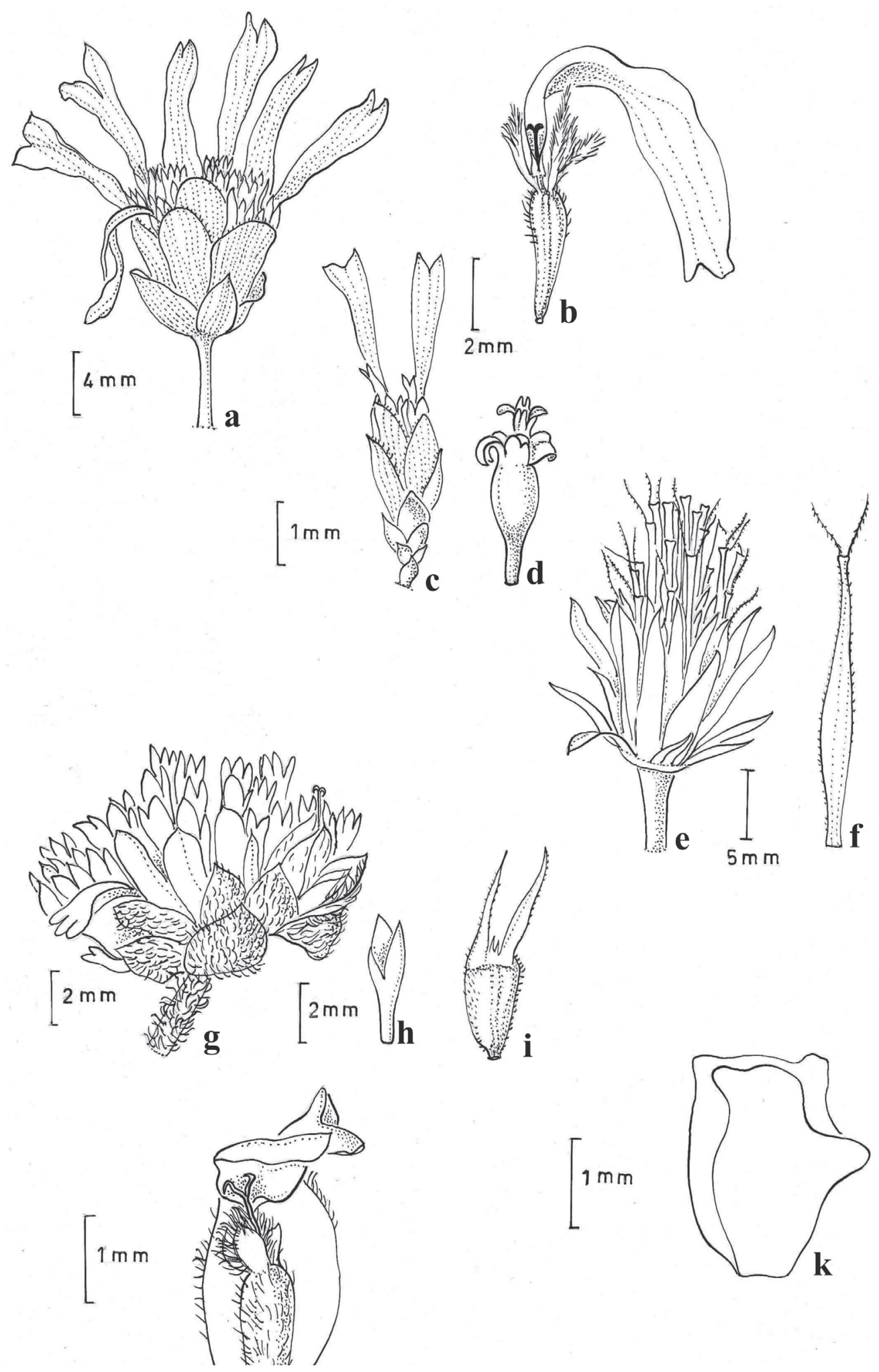

Figura 3: Representação esquemática dos gêneros de Heliantheae s.l. do Parque Estadual do Biribiri. a-d. Calea. a. Capítulo campanulado. b. Flor do raio. c. Capítulo cilíndrico. d. Flor do disco. e-f. Cosmos. e. Capítulo. f. Cipsela. g-i. Dimerostemma. g. Capítulo. h. Flor do raio. i. Cipsela. j. Galinsoga. Flor do raio e pálea. k. Melampodium. Cipsela.

Figure 3: Schematic representation of the genera of Heliantheae s.l. from Parque Estadual do Biribiri. a-d. Calea. a. Campanulate head. b. Ray floret. c. Cylindrical head. d. Disk floret. e-f. Cosmos. e. Head. f. Cypsela. g-i. Dimerostemma. g. Head. h. Ray floret. i. Cypsela. j. Galinsoga. Ray floret and palea. k. Melampodium. Cypsela. 


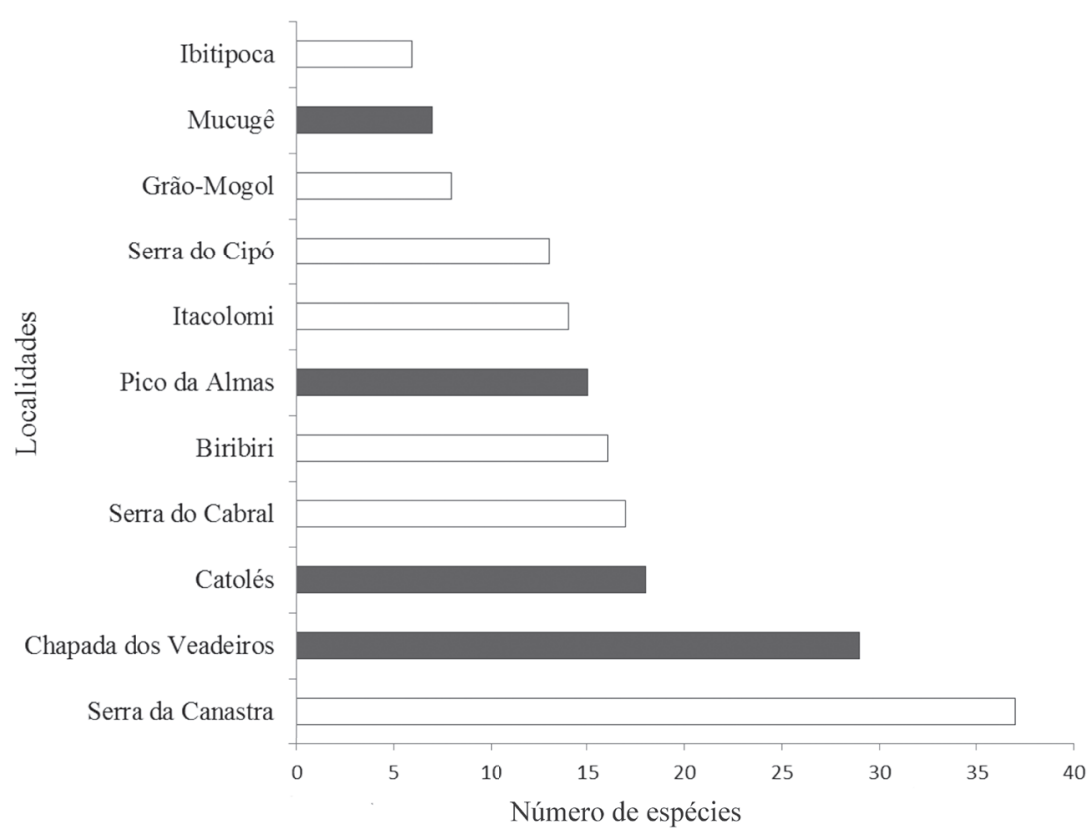

Figura 4: Número de espécies de Heliantheae s.l. ocorrentes nas regiões de campo rupestre do Brasil.

Figure 4: Number of species of Heliantheae s.l. occurring in regions of rocky fields (campo rupestre) of Brazil.

distinta dessa última por seu indumento pouco piloso ou ausente (vs. densamente piloso), brácteas involucrais externas em número de 2 a 4 (vs. 1-2), brácteas involucrais internas e páleas persistentes (vs. caducas) e flores do raio ausente ou quando presente 1,5(-2) mm compr. (vs. presente com 2,5 mm compr.) (Canne 1977). Galinsoga parviflora juntamente com Acanthospermum australe são as únicas espécies do PEB que possuem flor do raio branca, mas G. parviflora difere por suas cipselas lisas, as brácteas internas livres das cipselas e presença de pápus.

16. Melampodium perfoliatum (Cav.) Kunth, Nov. Gen. Sp. (folio ed.) 4 (17): 215. 1820.

Figura $3 \mathrm{k}$

Subarbusto ereto, ca. 0,5 m alt.; ramos achatados, estriados, esparsamente estrigosos. Folhas inteiras, opostas, sésseis, lâmina 7,5-10 ×6,3-9,1 cm, rômbica, ápice agudo, margem esparsamente serreada, base auriculada, faces estrigosas, glanduloso-pontuadas, nervação acródroma. Capítulos radiados, solitários, pedúnculo 3,2-5,5 cm compr.; invólucro $24-31 \mathrm{~mm}$ diam., largamente campanulado; receptáculo convexo; páleas elípticas, glabras, ápice agudo; brácteas involucrais 2 séries, foliáceas, esverdeadas ou alvas, externas 9,5-15,4 × 5,6-6,9 mm, elípticas, glabras, ápice arredondado, internas adnatas ao fruto. Flores do raio ca. 9, pistiladas, corola ca. 7,5 mm compr., liguliforme, amarela, estrigoso-glandulosa, 14-16-nervada. Flores do disco ca. 55, funcionalmente estaminadas, corola ca. 4,2 mm compr., infundibuliforme, amarela, glandulosa; anteras marrons, ápice agudo, base sagitada a obtusa; estilete ca. 6-6,4 mm compr. Cipselas do raio 5-5,5 mm compr., gibosas, lisas, glabras; cipselas do disco ausentes. Pápus ausente.

Material examinado: BRASIL. Minas Gerais: Diamantina, PEB, Alto da Guinda, $18^{\circ} 10.364^{\prime} \mathrm{S}$ 4338.048'W, 1.291 m.s.m., 15-XII-2011, D. Marques \& I.M. Araújo 407 (HUFU).

Segundo Lorenzi (2000), é originária do México. A espécie foi coletada em área antropizada próximo a cerrado, com flor e fruto em dezembro. As flores do raio amarelas, ambas as faces foliares estrigosas, brácteas involucrais externas com margem membranácea e folhas conspicuamente perfoliadas diferem M. perfoliatum de todas as outras espécies de Melampodium de acordo com Stuessy (1972). No Parque, Melampodium perfoliatum é de fácil identificação por apresentar folhas rômbicas com base auriculada.

\section{Considerações Finais}

A tribo Heliantheae s.l., apesar de aparentemente possuir poucas espécies no Parque Estadual do Biribiri, apresenta grande riqueza quando comparada com outras regiões de campos rupestres estudadas no Brasil. 
No Parque Nacional da Serra da Canastra e na Chapada dos Veadeiros a tribo está representada por 37 e 29 espécies, respectivamente (Munhoz \& Proença 1998, Nakajima 2000). Essa representatividade é elevada quando comparada com as demais regiões estudadas: Catolés, BA, com 18 espécies (Hind 2003b); Serra do Cabral, MG, com 17 espécies (Hatschbach et al. 2006); Parque Estadual do Biribiri, MG, com 16 espécies; Pico das Almas, BA, com 15 espécies (Hind 1995); Parque Estadual do Itacolomi, MG, com 14 espécies (Almeida 2008); Serra do Cipó, MG, com 13 espécies (Leitão-Filho \& Semir 1987); Grão-Mogol, MG, com oito espécies (Hind 2003a); Mucugê, BA, com sete espécies (Harley \& Simmons 1986) e Parque Estadual do Ibitipoca, MG, com seis espécies (Borges et al. 2010) (figura 4).

Isto pode ser explicado pelo fato de Heliantheae $s . l$. ter uma maior diversidade específica no escudo central brasileiro do que ao longo da Cadeia do Espinhaço nos Estados de Minas Gerais e Bahia.

No entanto, a comparação da representatividade de Heliantheae $s . l$. apenas para as regiões de campos rupestres que ocorrem no Estado de Minas Gerais indica que a tribo no Parque ocupa a terceira posição. É precedida apenas pelo Parque Nacional da Serra da Canastra e Serra do Cabral que possuem áreas bem maiores, 79.525 ha e 250.000 ha, respectivamente, quando comparadas com o tamanho do PEB com 16.998,66 ha (figura 4). A mesma posição é ocupada pelo PEB, quando a comparação é feita entre as regiões da Cadeia do Espinhaço, mas neste caso a primeira e segunda posições são ocupadas por Catolés e Serra do Cabral, respectivamente. Catolés também possui uma área superior a do PEB, com cerca de 80.000 ha (figura 4).

Importante destacar também que apesar do levantamento florístico realizado neste trabalho ter sido conduzido em uma Unidade de Conservação, observa-se habitats degradados dentro do PEB. Essa degradação é evidenciada pela existência de espécies ruderais ou exóticas de Heliantheae s.l., como Acanthospermum australe, Bidens pilosa, Cosmos sulphureus, Galinsoga parviflora e Melampodium perfoliatume (Lorenzi 2000), que representam uma ameaça para as espécies nativas da área, sobretudo as espécies endêmicas.

Finalmente, o Cerrado e o Estado de Minas Gerais possuem os maiores números de espécies de Asteraceae ameaçadas de extinção do Brasil (Nakajima et al. 2012b). Para que haja sua conservação, devem continuar a ser realizados trabalhos de inventários florísticos, para complementação das informações sobre as espécies pouco conhecidas, proporcionando assim bases científicas para a conservação das áreas ameaçadas.

\section{Agradecimentos}

Ao Programa de Pós-Graduação em Biologia Vegetal da Universidade Federal de Uberlândia, pelo auxílio às viagens de coleta e visitas a herbários; à CAPES, pela concessão da Bolsa de Mestrado ao primeiro Autor (PROTAX proc. 562290/2010-9); ao Instituto de Botánica del Nordeste, pelo apoio técnico. $\mathrm{O}$ segundo Autor agradece à CAPES, pela Bolsa de Pós-Doutorado (BEX proc. 9612/12-6). Os autores agradecem ao CNPq, CAPES, FAFs (REFLORA proc. 563541/2010-5, PROTAX proc. 562290/2010-9), por financiarem os estudos com a família Asteraceae no Brasil; à ilustradora Laura Simón que, gentilmente, preparou as ilustrações aqui apresentadas.

\section{Literatura citada}

Almeida, G.S.S. 2008. Asteraceae Dumort. nos campos rupestres do Parque Estadual do Itacolomi, Minas Gerais, Brasil. Tese de Doutorado, Universidade Federal de Viçosa, Viçosa.

Baldwin, B.G. 2009. Heliantheae alliance. In: V.A. Funk, A. Susanna, T.F. Stuessy, R.J. Bayer (eds). Systematics, Evolution, and Biogeography of Compositae. Smithsonian Institution, Washington, pp. 689-711.

Blake, S.F. 1921. Revision of the genus Acanthospermum. Department of Botany, Smithsonian Institution 20: 383-392.

Borges, R.A.X., Saavedra, M.M., Nakajima J.N. \& Forzza, R.C. 2010. The Asteraceae flora of the Serra do Ibitipoca: analyses of its diversity and distribution compared with selected areas in Brazilian mountains ranges. Systematics and Biodiversity 8: 471-479.

Canne J.M. 1977. Revision of the genus Galinsoga (Compositae: Heliantheae). Rhodora 79: 319-389.

Echternacht, L., Trovó, M., Oliveira, C.T. \& Pirani, J.R. 2011. Areas of endemism in the Espinhaço Range in Minas Gerais, Brazil. Flora 206: 782-791.

Funk, V.A., Susanna, A., Stuessy, T.F. \& Bayer, R.J. 2009. Systematics, Evolution and Biogeography of Compositae. Smithsonian Institution, Washington.

Giulietti, A.M. \& Pirani, J.R. 1988. Patterns of geographic distribuition of some plants species from the Espinhaço Range, Minas Gerais and Bahia, Brazil. In: W.R. Heyer \& P.E. Vanzolini (eds.). Proceedings of a workshop on Neotropical Distribution Patterns. Academia Brasileira de Ciências, Rio de Janeiro, pp. 39-69. 
Giulietti, A.M., Menezes, N.L., Pirani, J.R., Meguro, M.L. \& Wanderley, M.G.L. 1987. Flora da Serra do Cipó, Minas Gerais: caracterização e lista das espécies. Boletim de Botânica da Universidade de São Paulo 9: 1-151.

Giulietti, A.M., Harley, R.M., Queiroz, L.P., Wanderley, M.G.L. \& Pirani, J.R. 2000. Caracterização e endemismos nos campos rupestres da Cadeia do Espinhaço. In: T.B. Calvacanti \& B.M.T. Walter (eds.). Tópicos Atuais de Botânica. EMBRAPA Recursos Genéticos, Brasília, pp. 311-318.

Harley, R.M. \& Simmons, N.A. 1986. Florula of Mucugê, Chapada Diamantina, Bahia, Brazil. Royal Botanic Gardens, Kew.

Hatschbach, G., Guarçoni, E.A.E., Sartori, M.A. \& Ribas, O.S. 2006. Aspectos fisionômicos da vegetação da Serra do Cabral - Minas Gerais - Brasil. Boletim do Museu Botânico Municipal 67: 1-33.

Hind, D.J.N. 1995. Compositae. In: B.L. Stannard (ed.). Flora of the Pico das Almas, Chapada Diamantina, Brazil. Royal Botanical Gardens, Kew, pp. 175-278.

Hind, D.J.N. 2003a. Flora of Grão-Mogol, Minas Gerais: Compositae (Asteraceae). Boletim de Botânica da Universidade de São Paulo 21: 179-234.

Hind, D.J.N. 2003b. Compositae. In: D.C. Zappi, E. Lucas, B.L. Stannard, E.N. Lughadha, J.R. Pirani, L.P.Queiroz, S. Atkins, D.J.N. Hind., A.M. Giulietti, R.M. Harley \& A.M. Carvalho (eds.). Lista das Plantas Vasculares de Catolés, Chapada Diamantina, Bahia, Brasil. Boletim de Botânica da Universidade de São Paulo, v. 21, n. 2, pp. 345- 398.

IEF- Instituto Estadual de Florestas. 2004. Plano de Manejo do Parque Estadual do Biribiri. vol. 1. IEF, Curitiba.

Karis, P.O. \& Ryding, O. 1994. Tribe Heliantheae. In: K. Bremer (ed.). Asteraceae: Cladistics and classification. Timber Press, Portland, pp. 559-625.

Leitão-Filho, H.F. \& Semir, J. 1987. Compositae. In: A.M. Giulietti; N.L. Menezes; M. Meguro \& M.G.L. Wanderley (eds.). Flora da Serra do Cipó, Minas Gerais: caracterização e lista de espécies. Boletim de Botânica Universidade de São Paulo, v. 9, pp. 29-41.

Lorenzi, H. 2000. Plantas daninhas do Brasil: terrestres, aquáticas, parasitas, tóxicas e medicinais. 3 ed. Instituto Plantarum, Nova Odessa.

Magenta, M.A.G. 2006. Viguiera Kunth (Asteraceae, Heliantheae) na América do Sul e sistemática das espécies do Brasil. Tese de Doutorado, Universidade de São Paulo, São Paulo.

Magenta, M.A.G. \& Pirani, J.R. 2014. Novidades taxonômicas em Aldama (Asteraceae-Heliantheae). Rodriguésia 65: 175-192.

Moraes, M.D. \& Semir, J. 2009. A revision of Brazilian Dimerostemma (Asteraceae, Heliantheae, Ecliptinae), with a new species and taxonomic adjustments. Brittonia 61: 341-365.
Munhoz, C.B.R. \& Proença, C. 1998. Composição florística do município de Alto Paraíso de Goiás na Chapada dos Veadeiros. Boletim do Herbário Ezechias Heringer 3: 102-150.

Nakajima, J.N. 2000. A família Asteraceae no Parque Nacional Serra da Canastra, Minas Gerais. Tese de Doutorado, Universidade Estadual de Campinas, Campinas.

Nakajima, J., Loeuille, B., Heiden, G., Dematteis, M., Hattori, E.K.O., Magenta, M., Ritter, M.R., Mondin, C.A., Roque, N., Ferreira, S.C., Teles, A.M., Borges, R.A.X., Monge, M., Bringel Jr., J.B.A., Oliveira, C.T., Soares, P.N., Almeida, G., Schneider, A., Sancho, G., Saavedra, M.M., Liro, R.M., Souza-Buturi, F.O., Pereira, A.C.M. \& Moraes, M.D. 2012a. Asteraceae. In: Lista de Espécies da Flora do Brasil. Jardim Botânico do Rio de Janeiro. Disponível em http://floradobrasil. jbrj.gov.br/2012/FB000055 (acesso em XII-2012).

Nakajima, J.N., Junqueira, T.V., Freitas, F.S., Teles, A.M. 2012b. Comparative analysis of red lists of the Brazilian flora: Asteraceae. Rodriguésia 63: 39-54.

Panero, J.L. 2007. Key to the tribes of the Heliantheae alliance. In: J.W. Kadereit \& C. Jeffrey (eds.). The Families and Genera of Vascular Plants: Flowering Plants. Eudicots. Asterales. Springer, Berlim, v. 8, pp. 391-395.

Prance, G.T., Beentje, H., Dransfield, J. \& Johns, R. 2000. The tropical flora remains undercollected. Annals of the Missouri Botanical Garden 87: 67-71.

Pruski J.F. 1998. Novelties in Calea (Compositae: Heliantheae) from South America. Kew Bulletin 53: 683-693.

Pruski, J.F. \& Urbatsch L.E. 1988. Five species of Calea (Compositae: Heliantheae) from Planaltine Brazil. Brittonia 40: 341-356.

Radford, A. 1986. Fundamentals of plant systematics. Harper \& Row, New York.

Rapini, A., Mello-Silva, R.D \& Kawasaki, M.L. 2002. Richness and endemism in Asclepiadoideae (Apocynaceae) from the Espinhaço Range of Minas Gerais, Brazil - a conservationist view. Biodiversity and Conservation 11: 1733-1746.

Roque, N. \& Bautista, H. 2008. Asteraceae: Caracterização e morfologia. EDUFBA, Salvador.

Robinson, H. 1981. A Revision of the Tribal and Subtribal limits of the Heliantheae (Asteraceae). Smithsonian Contribution to Botany 51: 1-52.

Santos, J.U.M. 2001. O gênero Aspilia Thou. (AsteraceaeHeliantheae) no Brasil. 1 ed. Museu Paraense Emílio Goeuldi, Belém.

Sherff, E.E. 1932. Revision of the genus Cosmos. Publications of the Field Columbian Museum, Botanical Series 8: 399-448. 
Sherff, E.E. 1937. The genus Bidens. Field Museum of Natural History, Botanical Series 16: 1-485.

Stuessy, T.F. 1970. The genus Acanthospermum (CompositaeHelinatheae - Melampodinae): Taxonomic changes and generic affinibties. Rhodora 72: 106-109

Stuessy, T.F. 1972. Revision of the genus Melampodium (Compositae: Heliantheae). Rhodora 74: 1-70.

Thiers, B. 2012 [continuously updated]. In: Index Herbariorum: A global directory of public herbaria and associated staff. New York Botanical Garden's Virtual Herbarium. Disponível em http://sweetgum.nybg.org/ ih/ (acesso em II-2013).
Unesco. 2005. Reserva da Biosfera da Serra do Espinhaço: Proposta de Criação. SEMAD-MG, Belo Horizonte.

Urbatsch, L.E., Zlotsky, A. \& Pruski, J.F. 1986. Revision of Calea sect. Lemmatium (Asteraceae: Heliantheae) from Brazil. Systematic Botany 11: 501-504.

Vitta, F. 2002. Diversidade e conservação da flora nos campos rupestres da Cadeia do Espinhaço em Minas Gerais. In: E.L. Araújo, A.N. Moura, E.V.S.B. Sampaio, L.M.S. Gestinari \& J.M.T. Carneiro (eds.). Biodiversidade, Conservação e Uso Sustentável da Flora do Brasil. Recife, Universidade Federal Rural de Pernambuco/Sociedade Botânica do Brasil, pp. 90-99. 